\title{
A FABULOSA INCURSÃO DE DINO BUZZATI NA LITERATURA INFANTIL
}

\author{
THE DINO BUZZATI'S FABULOUS INCURSION INTO CHILDREN'S LITERATURE
}

Mariarosaria FABRIS

Universidade de São Paulo neapolis@bol.com.br

\begin{abstract}
Resumo: O escritor italiano Dino Buzzati é mais conhecido por seus numerosos contos e, principalmente, pelo romance $O$ deserto dos tártaros (1940). Em A famosa invasão dos ursos na Sicília (1945), considerada, em geral, sua única incursão na literatura infanto-juvenil, ele oferece uma vasta gama de linguagens verbais e visuais. Ao criar essa fábula sobre ursos que deixam suas montanhas para conquistarem uma cidade dos homens, Buzzati, com frequência, rearranja o mesmo conteúdo de diferentes formas. Alguns autores sugerem que $A$ famosa invasão dos ursos na Sicília responde, de forma crítica, aos dramáticos acontecimentos históricos contemporâneos de sua composição e convidam a refletir sobre a relação entre a fábula e o que ela pretende representar. Esse livro ilustrado, no entanto, impõe-se antes pela criatividade que cativa o leitor, graças à complexa riqueza da interação entre palavras e imagens. O relato é confiado a um narrador onisciente, o qual, amiúde, provoca o humor com sua intrusão na narrativa, às vezes irreverente, amenizando a amarga reflexão que essa marcante obra propõe.
\end{abstract}

Palavras-chave: Literatura italiana. Literatura infanto-juvenil. Dino Buzzati. A famosa invasão dos ursos na Sicília. Livro ilustrado.

\begin{abstract}
The Italian writer Dino Buzzati is best known for his many short stories and especially for his novel The desert of the Tartars (1940). In The bears' famous invasion of Sicily (1945), that is generally considered its only incursion into children's literature, he offers a wide gamma of both verbal and visual languages. In creating his fable of the bears that leave their mountains and conquer a human city, Buzzati frequently recasts the same content in different forms. Some authors suggest that The bears' famous invasion of Sicily responds critically to the dramatic historical events contemporary to its composition and invites to think about the relationship between a fable and what it intend to represent. However, this picturebook distinguishes better for its creativity that captures the reader with the complex richness of its word and image interaction. The tale isentrusted to omniscient narrator who often generates humor through its intrusion into narrative, sometimes with irreverence, mitigating the sad reflection that this remarkable work proposes.
\end{abstract}

Keywords: Italian literature. Children's literature. Dino Buzzati. The bears' famous invasion of Sicily. Picturebook .

\section{Introdução}


Quando criança, Dino Buzzati ${ }^{1}$ havia se interessado pelas obras de Arthur Rackham, ilustrador de clássicos da literatura infanto-juvenil, como os contos dos irmãos Grimm (1900, 1909), As viagens de Gulliver (1900, 1909), de Jonathan Swift, Peter Pan in Kensigton Garden (1906), de James Matthew Barrie, Alice no país das maravilhas (1907), de Lewis Carroll, Os cavaleiros da távola-redonda (1917), de Howard Pyle, e Cinderela (1919), de Charles Perrault. O que o havia encantado no aquarelista inglês? Nas palavras do próprio escritor italiano: "Sua capacidade de representar atmosferas misteriosas, os espíritos das montanhas e dos bosques, as velhas casas encantadas, as nuvens, os nevoeiros, os sortilégios do Natal foi [...] amor à primeira vista. Era a plena realização das [...] fantasias mais íntimas" (VIGANÒ, 2010, p. XXIII). O gosto pela literatura havia sido motivado antes pelos contos tradicionais com que sua babá o entretinha do que pela escola, o que explica a matriz fantástica que predomina em sua obra.

A esse interesse literário somava-se 0 encantamento pelas paisagens dolomíticas, por aquelas "montanhas pontiagudas, reino do mistério e da pureza" (S.A., 2015, p. X): "As impressões mais fortes que eu tive quando criança pertencem à terra em que eu nasci, o Vale de Belluno, as selvagens montanhas que o rodeiam e os Alpes Dolomíticos tão próximos." (CARNAZZI, 2010, p. XXXV), declarou Buzzati.

Suas paixões perenes, portanto, serão a montanha, a literatura e o desenho, inclinações que se afirmaram na adolescência, quando começou a excursionar pelas serras e escreveu seu primeiro texto literário, a prosa poética La canzone alle montagne (1920). O diálogo entre artes visuais e verbais, que será uma constante na obra do escritor, já havia se manifestado em sua infância e juventude, não apenas em seu diário e nas cartas trocadas com um amigo e com a primeira namorada, bem como num desenho executado em consonância com o caráter gótico e fantástico de The haunted palace, cujo texto ele copiou à mão na mesma folha, inserindo-o na ilustração (1924). O poema que o inspirou era de Edgar Allan Poe, autor pelo qual começou a interessar-se por volta dos treze, quatorze anos, quando descobriu também Ernst Theodor Amadeus Hoffmann.

${ }^{1} \mathrm{O}$ escritor nasceu em San Pellegrino (distrito de Belluno, no Vêneto), em 18 de outubro de 1906, e faleceu em Milão, em 28 de janeiro de 1972. 
A combinação texto-imagem instaurou-se na obra buzzatiana desde as primeiras publicações, como as novelas enviadas ao periódico I/ popolo di Lombardia (1931), Barnabo delle montagne (1933), em que desenhos simples e quase do tamanho de um selo, serviam também como letras capitulares, e // segreto del Bosco Vecchio (1935), cuja primeira edição contava com pequenas ilustrações mais elaboradas e pictóricas, eliminadas nas seguintes. No romance de 1935, o "fantástico" manifestava-se na antropomorfização da natureza, uma vez que seres inanimados e criaturas mudas ou que se comunicam por meio de outras linguagens não só se tornavam vivos ou adquiriam voz humana, como eram capazes de refletir, julgar e, consequentemente, agir, ou seja, de se comportarem como homens numa sociedade constituída. O fantástico literário de Buzzati não se confunde com o de um Tristan Todorov ("uma 'hesitação' entre o natural e o sobrenatural"), de um Jorge Luis Borges (o qual "o assimila ao caos"), de um Adolfo Bioy Casares ("um jogo filosófico ou intelectual") ou de um Franz Kafka ("para quem se casa ao absurdo trágico de uma condenação sem culpa") ${ }^{2}$, na opinião de Claudio Toscani (2014, p. VIII). Para esse autor, ao contrário:

O fantástico de Buzzati é um hino à infância, um espaço de liberdade, habitado pelo desejo de entender o mistério, o desconhecido, o plausível.

E o "Velho Bosque" é o éden perdido (o ancestral e o coletivo de toda a humanidade, e o pessoal e privado da virgindade consciencial dos primeiros anos de vida). O "Velho Bosque" é a selva sagrada, a floresta encantada da infância, onde se abriga a pura e desarmada criatividade da poesia.

Segundo o poeta Eugenio Montale, essa peculiaridade do escritor vêneto já estava presente em seu romance de estreia, Barnabo delle montagne, o qual

apresenta o primeiro personagem verdadeiramente original de Buzzati: uma gralha. A partir de então, deveria ter sido claro que os animais (e os homens) de Buzzati pertencem ao mundo interior de um homem para quem existe uma verdade, embora recôndita, e existe uma vida, embora traída pelo homem, que merece ser vivida (S.A., 1985, p. 7).

\footnotetext{
${ }^{2}$ Kafka, que Buzzati descobrirá apenas em 1934, é o autor com o qual sua literatura tem sido comparada amiúde, "uma aproximação insistente e justamente desagradável para o escritor, bem distante da negação sem saídas que se encontra na base da obra kafkiana", na opinião de Lazzarato (2001, p. 135). Quanto a Bioy Casares, a comparação é mais tênue. Buzzati, talvez, tenha querido prestar uma homenagem ao escritor argentino no topônimo que integra o título de seu último romance: A invenção de Morel (1940) e I miracoli di Val Morel (1971) compartilham da mesma sensação de deslocamento em relação à percepção comum de realidade.
} 
E é isso que estará presente em $A$ famosa invasão dos ursos na Sicília ( $L a$ famosa invasione degli orsi in Sicilia), publicada pela editora Rizzoli de Milão depois do fim da Segunda Guerra Mundial. Essa obra, geralmente, é considerada a única de Buzzati voltada para um público infanto-juvenil; no entanto, Francesca Lazzarato (2001, p. 146) lembra que, na década de 1970, Barnabo delle montagne havia sido proposto como leitura para o segundo grau (embora, pelos temas abordados, pareça mais dirigido aos adultos: o resgate de um erro do passado e a espera de um acontecimento que possa dar sentido à vida) e Maurizio Marchese (2016) acrescenta I/ segreto del Bosco Vecchio, que descreve como um "romance alegórico em forma de fábula". O fato de um dos protagonistas ser um garoto, que, ao crescer, deixará para trás os espíritos dos bosques e os animais falantes que haviam povoado sua infância, não quer dizer necessariamente que a obra se destinasse aos mais jovens. É antes uma fábula para adultos, como, aliás, também $A$ famosa invasão dos ursos na Sicília, segundo Giulio Carnazzi (2002, p. XXII), que a esse texto menos pessimista adiciona outros bem mais cruéis como "L'uccisione del drago" (1939), "Vecchio facocero" (1940) e "I reaziarii" (1947), todos posteriormente reunidos em Sessanta racconti (1958), nos quais os "monstros" não são os animais agonizantes (um sáurio que sobreviveu à sua espécie; um javali-africano; uma aranha), mas os homens (um conde; um caçador; um monsenhor) que os matam por estupidez, pelo sádico prazer de matar.

Essa capacidade que o escritor tinha de converter expressões artísticas em reflexões morais, em juízos sobre a humanidade, e de mesclar natural e sobrenatural, verossímil e inverossímil, crível e incrível, se manifestará também na fábula que cria no período final do conflito bélico, antes em forma de desenhos, depois enquanto narrativa, como ele mesmo explica:

naquela época, as filhas de meu cunhado vinham almoçar em casa, às quartas-feiras; findo o almoço, um dia comecei a esboçar desenhos. E a obra nasceu depois, dos desenhos. O texto não nasceu diretamente. Ele só foi escrito em seguida. Foi durante a guerra. E fiz os últimos desenhos logo após a guerra (TRUGLIO, 2011).

Não é de se estranhar o fato de essa história ter sido concebida antes visualmente e depois verbalmente, uma vez que, segundo Buzzati, as duas formas de expressão artística se equivaliam: "pintar e escrever, no fundo, são para mim a mesma coisa. Ao pintar ou ao escrever, eu persigo o mesmo objetivo, que é o de 
contar histórias". "É sempre literatura. Conta-se algo com a caneta e conta-se algo com os pincéis. É igual”. (CARNAZZI, 2002, p. XLVII; ADAMOVIT, 2013).

A versão original da fábula, dividida em duas partes - $A$ famosa invasão dos ursos (La famosa invasione degli orsi) e Velhos ursos, adeus! (Vecchi orsi addio!) havia sido divulgada no periódico infantil Corriere dei piccoli, entre 7 de janeiro e 18 de fevereiro (capítulos um a sete da primeira parte) e entre 8 e 29 de abril de 1945 (capítulos catorze a dezessete da segunda, que permanecerá incompleta). Cada um dos onze capítulos ocupava oito páginas e era acompanhado de uma grande ilustração colorida e pequenos desenhos também coloridos, que, ao ocuparem dois terços da página, sobrepujavam o texto. A publicação foi interrompida de vez durante o conturbado período que se seguiu ao término do conflito armado na Itália (25 de abril) e, para ser editada em livro, passou por uma cuidadosa revisão. Parte dos desenhos originais foi eliminada, a fábula foi reescrita pelo autor em tons mais leves, com a fusão das duas partes (a primeira mais épica; a segunda mais reflexiva), a introdução das estrofes e a expansão da cronologia dos acontecimentos de cinco para treze anos; ademais, a obra recebeu o acréscimo da apresentação das personagens e dos cenários, colocada antes da trama propriamente dita, e o novo local da ação (da Maremma, região costeira entre a Toscana e o Lácio, passase para a Sicília) levou à mudança no título.

A famosa invasão dos ursos na Sicília narra a história de Leôncio, rei dos ursos, o qual, ao ter seu filhote Tônio capturado por dois caçadores (que tinham se aventurado até os altos cumes), prefere dizer a seu povo que o pequeno havia morrido ao cair de um penhasco. Os anos passam para o atormentado pai, até que um dia, quando a fome aperta por causa de um inverno muito rigoroso, aceita a sugestão de seus súditos de descerem para a planície, em busca de comida, nem que, para isso, tenham que enfrentar os homens. Nem o rei, esperançoso de encontrar sua cria, nem os outros ursos, no entanto, tinham noção da maldade dos homens.

Começa, assim, uma atribulada viagem de iniciação, pois as boas feras terão de superar muitos obstáculos antes de alcançarem seu objetivo: lutar contra o aguerrido exército do Grão-Duque; repelir o ataque das hostes do Senhor de Molfetta, primo e aliado do tirano da Sicília, formadas por javalis treinados para a 
guerra, que a magia do Prof. De Ambrosiis transforma em balões; confraternizar com os espíritos de uma cidadela endemoninhada, para cujo castelo em ruínas os havia atraído o mago, na esperança de assustá-los; graças à astúcia do urso Esmeril, escapar, não antes de uma hecatombe, das garras do enorme e terrível gatopapão ${ }^{3}$, que o ogro Troll havia trancado numa jaula em seu castelo, a fim de garantir suas provisões; expugnar, por meio das engenhocas inventadas pelo urso Grandifloro depois das grandes baixas sofridas, a fortaleza que protegia a capital do grão-ducado; aguentar o baque pela aparente morte do reencontrado Tônio, atingido por um disparo do Grão-Duque para vingar-se da derrota sofrida. Com a eliminação do Grão-Duque, crivado de balas, e a ressurreição de Tônio, graças à intervenção de De Ambrosiis, começam os festejos pelo reinado de Leôncio, que passa a governar o território conquistado.

E lá se vão treze anos, durante os quais, para desgosto de seu rei, muitos dos ursos instalados na cidade adquiriram os hábitos dos homens. Coisas estranhas começam a acontecer no reino - o roubo da varinha de condão do mago; o surgimento de um misterioso palácio no Parque das Globigerinas, onde ursos se embebedam; o assalto ao Grande Banco Universal -, mas, apesar das evidências e dos avisos, Leôncio prefere imputar a culpa aos homens, até que, alertado por um bilhete do urso Jasmim, se dirige, incógnito e disfarçado, a uma casa clandestina de jogos, onde, para seu espanto, encontra o filho. O soberano, finalmente, resolve convocar todos os súditos, homens e ursos, mas Salitre, o astuto camareiro-mor, o distrai de seu intento, mostrando o projeto de uma estátua faraônica a ser erguida em sua homenagem. Envaidecido, o rei esquece seus propósitos, mas, quando o monumento está quase pronto, surge uma ameaça para a cidade: uma enorme serpente marinha, que assusta a todos. Leôncio se apressa a enfrentá-la e consegue atingi-la com um arpão, enquanto outros ursos disparam, dentre eles Salitre, que não mira o perigoso inimigo, mas as costas de seu senhor, sendo em seguida decapitado por Jasmim.

\footnotetext{
${ }^{3}$ A expressão "gatto mammone" corresponde, em português, a "bicho-papão". Na versão brasileira da fábula de Buzzati (2001) foi traduzida por "gato-mamão", quando poderia ter-se optado por "gatopapão", em virtude da presença do felino na história. O "gatto mammone", além de ser um monstro imaginário evocado para assustar as crianças, representa o espírito do mal, o demônio, o princípio da danação.
} 
Mortalmente ferido, o rei pede a seu povo que abandone a cidade e suas fúteis tentações e que volte para as montanhas, onde quer ser sepultado. Com sua morte sacrifical, Leôncio mostra que amadureceu, pois dessa vez enfrentou abertamente o inimigo - a serpente do mar - e não se escudou atrás de uma mentira, como quando Tônio foi raptado. Mais importante ainda, indicou aos demais ursos o caminho da salvação: a volta às montanhas, às origens. $E$, por meio dele, o narrador advertiu os homens, pois como aponta Lazzarato (2001, p. 151):

o relato que se desenrola através dos doze capítulos da Famosa invasão é também uma representação das idades da vida. Das montanhas da infância se passa ao rico vale da adolescência, e depois à cidade em que se conhecerão as desilusões da maturidade, para voltar, enfim, para o lugar de onde se veio e desaparecer num ilimitado, definitivo silêncio.

O fato de $A$ famosa invasão dos ursos na Sicília ter sido concebida e reelaborada em 1945 levou a muitas conjecturas sobre de que invasão se tratava e quem eram os ursos, ou seja, a associações com os acontecimentos da época. Interpretações possíveis, mas, às vezes, um pouco forçadas, dado que pressupõem uma correspondência exata entre a fábula engendrada e os fatos que abalaram a Itália naquele período. Em primeiro lugar, a Sicília descrita na obra não é real, mas inventada, com suas "majestosas montanhas", "cobertas de neve", que remetem às paisagens alpinas da infância do escritor, e atemporal, pois a história se passa "no tempo dos tempos" (BUZZATI, 2001, p. 11, 5). As feras, que Ugo Fracassa (TRUGLIO, 2011) compara aos soldados norte-americanos - os quais, ao desembarcarem na Sicília, em 10 de julho de 1943, deram início à luta pela libertação da Itália do jugo dos nazifascistas -, não são combatentes aguerridos, não correspondendo, portanto, nem à tradição daqueles guerreiros que, nas sagas nórdicas, se cobriam com peles de urso para assimilarem sua coragem e seu vigor:

Ignoravam os ursos, incluindo Rei Leôncio, quem fossem de fato os homens, tão maus quanto astutos, que armas terríveis possuíam, que armadilhas sabiam inventar para aprisionar os animais. [...]

O que podem os ursos com lanças, flechas e atiradeiras contra fuzis, escopetas, canhões e canhoneiras?

[...] o castelo tem muralhas altas. Cada uma da grossura de umas vinte casas comuns, centena de artilheiros armados até os dentes estão a postos nas beiras dos bastiões, os canhões exibem suas bocas negras pelas ameias [...].

Os ursos, entoando hinos patrióticos, lançaram-se ao assalto. Mas como? Mas como? Com espingardas e baionetas contra as muralhas de pedra e os portões de ferro? Lá em cima foi um crepitar de golpes, chamas, fumaça e gritos, parecia o fim do mundo. E alguém do alto da fortaleza atirava para baixo até enormes pedregulhos (BUZZATI, 2011, p. 17,19, 58, 59). 
Os animais irão conquistar aos poucos as manhas da guerra, pois, enquanto viviam nas cavernas das altas montanhas da Sicília se preocupavam apenas em comer e hibernar: Babbone faz imensas bolas de neve, que abatem as hostes do Grão-Duque; os ursos se armam com as espingardas tomadas às tropas do tirano; Esmeril faz explodir o gato-papão com uma bomba também subtraída ao inimigo; Grandifloro cria um enorme morteiro, uma gigantesca catapulta e escadas imensas para que os ursos possam assaltar as muralhas da fortaleza. Assim sendo, evocariam antes os partisans, ou seja, civis que se tornaram combatentes em virtude das circunstâncias, no fim da Segunda Guerra Mundial.

Nessa linha de pensamento, para alguns, as engenhocas de Grandifloro e os javalis que "inflavam feito bexigas" (BUZZATI, 2011, p. 30), aludiriam às novas armas bélicas empregadas durante a Segunda Guerra Mundial, enquanto os traços caricaturais do Grão-Duque, com seu nariz de águia, remeteriam a características físicas marcantes de figuras ditatoriais (os bigodinhos pretos de Adolf Hitler; a careca e a mandíbula de Benito Mussolini) e seus desmandos corresponderiam aos abusos das forças alemãs, principalmente no paralelo que poderia ser estabelecido entre as blitzen que dizimavam a população italiana e a matança que o tirano da Sicília perpetra, para evitar que se cumpra a profecia da invasão de seus domínios, matança que apenas um ou outro autor relaciona com o bíblico massacre dos inocentes a mando de Herodes:

o professor De Ambrosiis, astrólogo da corte, havia profetizado que das montanhas desceria uma armada invencível, que o Grão-Duque seria derrotado e que o inimigo havia de apoderarse do reino inteiro.

[...] Mas imaginem o Grão-Duque. [...] como era supersticioso, ordenou a seus soldados que subissem às montanhas e matassem todos os seres vivos que encontrassem. Assim, pensava, não sobraria ninguém nos montes e ninguém poderia descer para conquistar seu reino.

Os soldados partiram armados até os dentes e sem misericórdia acabaram com todos os seres vivos encontrados lá em cima: eram velhos lenhadores, pastores, esquilos de vários tamanhos e cores, marmotas e até passarinhos inocentes (BUZZATI, 2011, p. 18).

A conquista do grão-ducado e o consequente convívio pacífico entre homens e ursos - "Aqui nos reencontramos, como se nada fosse, depois de treze anos da última vez que nos vimos e o Rei Leôncio ainda reina sem confusão na Sicília, pois ninguém jamais teve a coragem de desafiá-lo (BUZZATI, 2011, p. 87) - levou a especulações sobre uma visão crítica de Buzzati com relação às aspirações 
coloniais italianas na África (onde ele esteve como correspondente entre 1939 e 1940) e ao consenso das massas buscado pelo Fascismo depois de sua consolidação no poder, por meio do controle da opinião pública e de seu direcionamento em favor do novo regime. Ao mesmo tempo, a pergunta que Tônio faz ao pai em seu leito de morte - "Quem há de comandar agora o nosso povo?" (BUZZATI, 2011, p. 123) - ecoaria uma preocupação do povo italiano com o justiçamento do duce, o enfraquecimento da monarquia e o surgimento de novas forças políticas. Classificado de patriarcal e marcial, em virtude das características que the atribui o narrador - "É o Rei dos ursos: filho de um Rei que por sua vez tinha um Rei como pai; portanto, um urso nobilíssimo. É grande forte corajoso bom (e além do mais inteligente, embora nem tanto)" (BUZZATI, 2011, p. 7) - Leôncio pertenceria à galeria dos heróis cultuados pelo Fascismo (sem se reparar na ironia do atributo colocado entre parênteses), como Giuseppe Garibaldi, do qual o protagonista da fábula seria uma encarnação.

Dessa forma, tem-se a sensação de que alguns intérpretes da obra buzzatiana atiraram em muitas direções, a esmo, sem atingir um alvo específico, quando talvez, como aponta Silvana Cirillo, o escritor quisesse apenas "evadir daquela realidade cinzenta projetando-se naquela sem dúvida mais colorida e atraente do mundo... dos desenhos e das ilustrações" (TRUGLIO, 2011). A primeira versão da fábula também não escapou de conjecturas. A entrada dos ursos na capital da Sicília, pintada como se fosse uma cidade nórdica, obrigou o escritor a refazer uma página colorida, pois o diretor do jornal teria detectado "uma alarmante semelhança" (LAZZARATO, 2011, p. 139) com o avanço das tropas soviéticas sobre Berlim, que se renderá em 2 de maio de 1945. Quanto à serpente do mar - que o narrador de I miracoli di Val Morel (BUZZATI, 2013, p. 36) definirá a "encarnação talvez do demônio da guerra" - poderia ser uma lembrança das batalhas navais das quais o escritor havia participado como correspondente de guerra, no início dos anos 1940. Neste último caso, porém, seria mais interessante pensar na serpente como uma manifestação do inconsciente, da angústia que aflige o ser por uma culpa inconfessável ainda não expiada:

Oh não, a minha vinda traz a vocês o segredo que ninguém conhece ainda 
desde o abismo negro (BUZZATI, 2011, p. 115).

Se as palavras da serpente forem interpretadas nesse sentido, isso faria de Leôncio um herói problemático, na linha do protagonista de Lord Jim (1900), no qual o escritor "confessa ter encontrado um de seus paradigmas" (CARNAZZI, 2002, p. $\mathrm{XI}$ ), desde Barnabo delle montagne, uma vez que, como o personagem de Joseph Conrad, também o jovem guardião (que se escondeu enquanto seus companheiros eram rendidos por bandidos) e o rei dos ursos, com um ato de coragem, se resgatam de um momento de covardia.

O que a maioria dos autores parece fazer questão de ignorar é que Buzzati havia aderido ao Fascismo, permanecendo fiel a seu ideário mesmo durante o período da chamada República de Saló ${ }^{4}$, provavelmente mais por uma questão de caráter (abraçar uma causa até o fim) do que de ideologia, tendo em vista que pôde voltar imediatamente às suas funções de jornalista do Corriere della Sera, logo no dia em que foi proclamado o fim da guerra na Itália, embora, ao contrário de outros colegas, dentre os quais Gaetano Afeltra, não tivesse abandonado a redação do prestigioso diário quando este se alinhou com os nazistas que se assenhorearam do Norte do país (9 de setembro de 1943). Afeltra (CARNAZZI, 2010, p. XLIII) assim lembra a volta de Buzzati ao noticioso milanês, o qual, no dia 26 de abril de 1945, ao sair com o cabeçalho II Nuovo Corriere, em sua primeira página, estampava "Cronaca di ore memorabili", em que o escritor relatava os acontecimentos que haviam levado à libertação da cidade: "Estava em casa como se não estivesse acontecendo nada, jantando com a mãe. Disse-Ihe para vir. Não se abalou, nem perguntou o porquê daquela única violação ao banimento de todos os colaboracionistas". Parece ser um tema tabu, ao qual, porém, o próprio Buzzati não se furtava (e dele se penitenciava), já que, em 5 de junho de 1945, ao confiar a um diário suas impressões sobre o fim da guerra, — quando a vida retomava seu curso

\footnotetext{
${ }^{4}$ A República Social Italiana (RSI), que será conhecida como República de Saló (em virtude da localização de seu comando nessa cidadezinha da Lombardia, às margens do Lago de Garda, e em outras pequenas localidades vizinhas) foi proclamada por Mussolini em 23 de setembro de 1943. Foi consequência da capitulação das forças italianas e da cessação das hostilidades contra as tropas angloamericanas (no dia 8 daquele mesmo mês). A Itália ficou dividida: enquanto o Sul, já libertado pelos Aliados, continuava a ser governado pela Monarquia, o Centro e o Norte estavam sob o domínio das divisões alemãs, que haviam se transformado em exército de ocupação, em virtude da declaração de guerra a seu país. A RSI durou até 25 de abril de 1945, quando a Resistência italiana conseguiu libertar as cidades do Norte.
} 
normal e a tranquilidade apaziguava os ânimos —, indagava-se sobre o que o ser humano havia feito para merecer o que a misericórdia divina estava lhe proporcionando: "Mas, isso não é uma brincadeira, um engano? Mudou, talvez, nossa condenação, que era tão justa?" (CARNAZZI, 2010, p. XLIII-XLIV). Isso tudo, no entanto, talvez seja irrelevante para os leitores de hoje, para os quais o que se impõe é a força da fábula buzzatiana. Como sublinha Carnazzi (2002, p. XXIV):

É grande a tentação de insistir sobre as referências à atualidade, de perseguir as possíveis correspondências entre as guerras dos ursos e os trágicos acontecimentos daqueles anos. [...] Mas, cuidado para não forçar o sentido desses indícios; em $A$ famosa invasão dos ursos na Sicília contam mais os achados de uma verve narrativa que é livre sem ser gratuita, a revisitação paródica de lugares romanescos consolidados e aquele cativante veio de ironia e humorismo que permanecerá como marca de largos trechos da obra buzzatiana. Na sempre variada e cambiante posologia com a qual Buzzati combina os dados da invenção, da fabulação e da alegoria, o que prevalece aqui é a reivindicação do prazer de narrar.

E o prazer da leitura, que poderá ser compartilhado por leitores de todas as idades, como observa Lazzarato (2011, p. 146-147):

\begin{abstract}
Para as crianças, eis o encanto de inúmeros achados e surpresas, da aventura e do fabular, da magia e do enredo, de um delicado e irresistível humorismo, do arrepio provocado pela aparição de monstros e fantasmas, mas também a profundidade de uma mensagem que não tem nada de premeditado, nem exibe estigmas pedagógicos de nenhum tipo: porque esta é uma história sobre a coragem autêntica, sobre a amizade e a generosidade, sobre a importância de não se render ao luxo e ao poder, sobre a necessidade de cada um ser ele próprio e fazer o máximo, independentemente de como caminhem as coisas.

Para os adultos, ao contrário, representa a possibilidade de superar o limiar da infância toda vez que se desejar, sem abusar da nostalgia e do infantilismo, desfrutando, além do mais, dos múltiplos níveis de leitura de uma pequena obra perfeita e alegre, na qual são identificáveis quase todos os temas fundamentais de Buzzati "para adultos", desde que seja legítima uma distinção desse gênero, quando se fala de "um autor em que as competências do humorista, do fabulador, do trágico são na realidade complementares e interdependentes" ${ }^{\text {. }}$.
\end{abstract}

O que acresce o prazer da leitura são as ilustrações que o escritor havia criado antes de urdir a trama que as complementa. Adepto da pintura narrativa, Buzzati tinha concebido uma série de tábuas coloridas e desenhos de vários tamanhos para narrar a saga dos ursos. Quase sempre, a pequena figura que fecha cada capítulo remete à imagem de abertura, mas, quando isso não acontece, ela se refere a algum outro elemento presente naquele trecho da história. As ilustrações coloridas são as que se sobressaem pelo apuro do traço, pelo agenciamento espacial da composição, pela distribuição harmoniosa dos volumes, pela atenção dada aos detalhes, pela feliz escolha das cores e pelo equilíbrio dos tons. Cada uma dessas

${ }^{5}$ Nessa parte final, a autora está citando Carnazzi (2002, p. XXIII).

Pensares em Revista, São Gonçalo-RJ, n. 9, p. 105-122, 2016

DOI: $10.12957 / \mathrm{pr} .2016 .30910$ 
imagens alude sempre ao acontecimento mais importante, e, quando há mais de uma no mesmo capítulo (como no sete, no nove e no dez), a segunda se liga a outro momento significativo.

Em várias ocasiões, o narrador chama a atenção do leitor para o que é representado: ao falar da primeira batalha travada pelos ursos contra o exército do Grão-Duque, convidando a observá-la na tábua colorida ${ }^{6}$ e a deter-se na minúscula presença do Prof. De Ambrosiis no canto esquerdo da composição ${ }^{7}$; ao elencar o maquinário inventado por Grandifloro para a conquista da fortaleza ${ }^{8}$; ao relatar a comoção que toma conta de todos quando Tônio é ferido de morte pelo tirano, ressaltando o sentimento do mago $^{9}$; durante a festa pela conquista da capital, ao apontar para o astrólogo escondido num dos pequenos arcos da margem superior ${ }^{10}$; ao descrever o olhar de Leôncio, treze anos depois do início de seu reinado ${ }^{11}$, quando Buzzati quebra o padrão seguido até então, pois o desenho correspondente é em preto e branco.

As imagens acabam sendo reiterativas em relação à trama, ao ilustrarem o que nela é contado e, no caso das coloridas, estas trazem nas legendas o resumo do texto a que alude a representação (de tanto em tanto, com o acréscimo de algum detalhe) e pequenos desenhos que a sintetizam ${ }^{12}$. É como se cada passagem a que elas se referem fosse narrada quatro vezes (e até mais, quando as estrofes ecoam

\footnotetext{
${ }^{6}$ No original: "La battaglia va osservata / nella tavola colorata" (BUZZATI, 2002, p. 238). Em italiano, "tavola" pode referir-se tanto a "tábua", quanto a "mesa". Na versão brasileira, a escolha do termo correspondente em português não foi acertada, o que pode levar a interpretar que o Grão-Duque não estivesse presente no campo de batalha, mas seguindo o combate no mapa em que havia traçado sua estratégia: "A batalha será seguida / sobre a mesa colorida" (BUZZATI, 2011, p. 19).

7"Se observarem devagar / o desenho do combatimento / verão um tipo singular / no vau batido pelo vento" (BUZZATI, 2011, p. 25).

"Porque vocês próprios hão de ver o que acontece: / Dispara o supercanhão / e lá vai um urso de supetão / [...] / Depois vejam a catapulta: um segundo urso assustado / [...]/E as escadas? [...] / Algumas são quebradas / [...] / (Notem à direita, bem na beira / por exemplo, uma boa quebradeira. / [...] / Mas dentro em pouco dará para ver / o soldado com[o] um aríete se reerguer.)" (BUZZATI, 2011, p. 62-63).

9“"Até a barba do prof. De Ambrosiis, olhem para ele, treme um pouco" (BUZZATI, 2011, p. 73).

10، (o mago lá pelas tantas / espiava entre as plantas)" e "o recuperado prof. De Ambrosiis, não podendo participar por causa da idade, se satisfaz em olhar de um canto" (legenda) (BUZZATI, 2011, p. 82-83).

${ }^{11}$ “Contudo, observem os olhos do rei e perceberão que ele não é feliz. Muitas vezes o seu olhar, através dos janelões do palácio, corre tristemente para as montanhas que se erguem para além das mais altas torres da cidade" (BUZZATI, 2011, p. 88).

${ }^{12} \mathrm{~A}$ única imagem colorida que escapa dessa norma é a da captura de Tônio pelos caçadores, em que aparece apenas a legenda, a qual funciona como um preâmbulo da obra,
} 
trechos em prosa), numa interação constante entre a linguagem verbal e a visual. Há momentos em que as tábuas funcionam como uma espécie de elo entre o que já foi exposto e o que será relatado ou descrito em seguida. Nesse sentido, a tábua mais interessante é a que retrata o antro da rua La Bruyère, de onde Leôncio arranca seu filho que se dedicava à jogatina, pois ela sintetiza a narração sobre a chegada do rei e sua saída com Tônio e já apresenta todo o cassino antes que seja descrito no texto.

A representação do luxuoso estabelecimento recorda de imediato uma casa de boneca, que, ao ser aberta, revela o que está por trás da fachada. A tábua tem uma estrutura linear, dividida em quatro faixas quase simétricas (as duas últimas, de baixo para cima, são mais estreitas), cada uma com subdivisões internas. As grossas linhas pretas bem delineadas, que servem para indicar elementos arquitetônicos (pisos, tetos, portas, janelas), remetem às demarcações de uma página de histórias em quadrinhos, cuja leitura, porém, Buzzati inverte, ao propor que ela se dê de baixo para cima e da direita para a esquerda, fato normal por descrever uma casa e que acaba chamando muito mais a atenção sobre o Rei Leôncio, permitindo uma perfeita consonância entre escrita e imagem.

A capacidade de englobar numa única composição vários momentos de uma trama será uma característica constante na obra pictórica de Buzzati, principalmente naqueles quadros em que a simbiose entre imagem e palavra se faz presente e que ele denomina Le storie dipinte, título da exposição realizada em Milão, em 1958 (a fatura de histórias pintadas o ocupará também na década seguinte). Essa continuidade narrativa não era uma inovacão, pois, segundo Maria Truglio (2011), já havia sido empregada pelos escultores dos sarcófagos romanos e retomada por Masaccio em seus afrescos, como o célebre /l tributo della moneta, pintado em 1425 na Capela Brancacci (Igreja de Nossa Senhora do Carmo, Florença). O crítico de arte Gillo Dorfles (2005, p. 4), no entanto, vai mais longe e, ao mapear a genealogia das histórias em quadrinhos, lembra que, desde a época das cavernas - passando pelos hieróglifos egípcios e pelas obras de Benozzo Gozzoli, Paolo Uccello e Piero Della Francesca, dentre muitos outros exemplos - até o advento da arte abstrata, o ato de pintar sempre esteve ligado a uma narração, principalmente quando contou histórias para uma multidão de iletrados. 
Referências eruditas, sem dúvida, fazem parte do universo do escritor por sua formação e isso é atestado por outras ilustrações que dialogam com obras consagradas. Por exemplo, os vagalhões dos quais emerge a enorme serpente marinha evidenciam sua ligação com a estampa A grande onda (1830 ou 1831), de Katsushika Hokusai; as silhuetas pretas das bailarinas e do urso equilibrista, que emulam sombras chinesas, parecem inspirar-se também na ilustração Cinderela (1919), de Rackham; os pássaros que sobrevoam as altas torres durante a confraternização entre ursos e espectros, bem como a solitária ave noturna que acompanha os passos de Leôncio rumo à casa de jogos, têm ascendentes ilustres nos animais voláteis que circundam um homem repousando em $O$ sono da razão produz monstros (1797), de Francisco Goya; a cidadela endemoninhada, com seus edifícios periclitantes, e a soturna caminhada do rei em busca do cassino clandestino evocam estilemas e atmosferas do Expressionismo alemão, principalmente o cinematográfico. Por outro lado, não se pode esquecer que Buzzati não desdenhava gêneros mais populares, come pode ser constatado por suas leituras de livros para adolescentes - em 1971, ele prefaciará os dois primeiros volumes das aventuras de Tarzan, criadas pelo escritor norte-americano Edgar Rice Burroughs a partir de 1912 - e gibis, como os do Pato Donald. No prefácio de Vita e dollari di Paperon de' Paperoni (A saga do Tio Patinhas), em 1968, o escritor havia declarado seu encanto pelos quadrinhos, que considerava "uma das maiores invenções narrativas dos tempos modernos", acrescentando ainda sua apreciação pelo velho milionário pão-duro e seu desastrado sobrinho: "Sua estatura, como seres humanos, não me parece inferior à dos famosos personagens de um Molière, de um Goldoni, de um Balzac ou de um Dickens" (V.A., 2005, p. 11).

O convívio entre a cultura erudita e a popular caracteriza também o texto de $A$ famosa invasão dos ursos na Sicília, em que partes rimadas e trechos em prosa se alternam. Lembrando que essa obra foi definida "uma balada repleta de maravilha", Elisa Martini aponta, dentre suas fontes literárias, poemas de cavalaria - Orlando enamorado (1483-1495), de Matteo Maria Boiardo, e Orlando furioso (1516-1532), de Ludovico Ariosto - e outras manifestações como as composições dos jograis, as canções de gesta, as romanças, formas baseadas na oralidade, em que o público era convidado a escutar as histórias contadas. E o narrador do livro de Buzzati 
(2011, p. 15) faz o mesmo convite aos leitores, no trecho inicial da fábula, cujos versos emulam com leveza o tom épico das obras nas quais se inspiraram: "Agora vamos ouvir prestando bem atenção / dos ursos na Sicília a famosa invasão".

Convite renovado em outras ocasiões, como quando o astrólogo se apresenta ao rei dos ursos $^{13}$ ou quando é anunciado o relato do segundo fato misterioso que assombra o reino ${ }^{14}$. Se as imagens que o leitor é levado a olhar quebram a ilusão criada pela fabulação, porque o obrigam a atentar para "a materialidade do livro" (TRUGLIO, 2011), o mesmo acontece com os convites à escuta, que o arrancam de um ato isolado, a leitura, para integrá-lo num círculo maior de ouvintes - que podem ser solicitados a manifestar-se ${ }^{15}$-, no qual também o narrador está implicado, principalmente pelo emprego constante da primeira pessoa do plural:

Ai, o que é a vida. Pensamos ter tempo de sobra

Se atrasados, nem ligamos.

Depois a página se dobra

e já se passaram treze anos! (BUZZATI, 2011, p. 87) ${ }^{16}$

Um narrador onisciente, o qual, por conhecer a trama antes do que o leitor, se diverte, com certa irreverência, diante da perplexidade deste quando há uma discrepância entre o texto e a imagem que está observando:

E então por que no desenho, que certamente corresponde à verdade, ao contrário se veem os ursos chegando ao topo das muralhas e alguns até mesmo no telhado da fortaleza, ainda mais altos que os soldados do Grão-Duque? Por que no desenho parece que os ursos estejam a ponto de vencer? Por que então esta brincadeira?

Porque entretanto passaram-se sete dias, esta é a razão, e os ursos depois de terem batido vergonhosamente em retirada na primeira tentativa, preparam-se para um segundo assalto (BUZZATI, 2011, p. 60-61).

O que o narrador conhece, porém, é o que Ihe foi transmitido, por sua vez, por um ancião, que assim the responde ao ser indagado sobre umas pedras

\footnotetext{
13“"Ouçam agora como fala, quanta sabedoria sai de sua boca” (BUZZATI, 2011, p. 27).

14،"E aqui vão ouvir, meninos e meninas / O mistério do Parque das Globigerinas" (BUZZATI, 2011, p. 92).

15“"Bom? Mau? Cabe a vocês julgá-lo" (BUZZATI, 2011, p. 8) - diz o narrador a respeito do Prof. De Ambrosiis, na apresentação das personagens.

${ }^{16}$ Esse seria mais um trecho em que é chamada a atenção para o livro enquanto objeto, porque o decurso do tempo entre os capítulos sete e oito é assinalado pela passagem de uma pagina a outra. Esse detalhe, no entanto, se perdeu na versão brasileira, pois, para manter a rima, foi escolhido o verbo "dobrar" em vez de "virar" para traduzir "voltare": "Poi si volta pagina" (BUZZATI, 2002, p. 293). Com isso perdeu-se também a sutileza com que é introduzida a transformação dos ursos, uma vez que "voltare pagina" significa mudar de atitude, comportamento, hábitos; encerrar definitivamente uma experiência -, podendo corresponder à expressão "página virada", em português.
} 
abandonadas no canto de um jardim: "- Mas como? - Não sabe, senhor? São os restos de uma estátua antiga. Vê? No tempo dos tempos... E começou a contar" (BUZZATI, 2011, p. 129). A presença de um guardião da memória confere de vez o estatuto de ouvinte também ao narrador e assegura a continuidade da transmissão de uma história, que se perde na bruma dos tempos, para a geração seguinte. Uma transmissão que, seguindo a tradição dos contos populares, é oral antes de ser escrita. Por isso Buzzati faz da oralidade o traço dominante da linguagem empregada nesse livro e, para tanto, opta por uma língua comunicativa, clara, de uma rigorosa simplicidade, sem termos rebuscados, quase perto da fala do dia a dia, mas não isenta de poeticidade. A oralidade se faz presente não só nos trechos em prosa, bem como nos versos, os quais, mais do que nas formas literárias arroladas por Martini, levam a pensar nas filastrocche, ou seja, naquelas cantigas infantis que, com seu ritmo acelerado, suas rimas simples, às vezes assonantes, em que as palavras parecem perseguir-se de um verso para outro, embalaram também a infância do escritor e que, pela concatenação de situações, foram consideradas precursoras dos desenhos animados.

A filastrocca mais famosa, Volta la carta - que parece ter inspirado Buzzati na mudança de circunstâncias que se verifica na passagem do sétimo para o oitavo capítulo (virar a página = virar a carta) - descreve uma série de pequenos acontecimentos, cada um relativo a um personagem, que vão surgindo toda vez que se vira uma carta de tarô, até chegar à da Morte, depois da qual não há mais nada. A presença da morte, portanto, não era estranha às brincadeiras infantis como contraponto à vida e é sobre o confronto entre essas duas realidades que Buzzati estrutura sua fábula. Prenunciada nas várias baixas que os ursos sofrem nas lutas travadas, a morte, porém, não é assustadora, pois permite o reencontro com os que se foram, tanto na festa macabra, quanto no momento em que Leôncio se despede da vida:

Cerrou os olhos. Pareceu-lhe que sombras amáveis, os espíritos dos antigos ursos, dos antepassados, do pai, dos companheiros caídos na batalha, se aproximaram dele para acompanha-lo ao distante paraíso dos ursos, onde existe primavera eterna. E terminou a vida com um sorriso (BUZZATI, 2011, p. 125).

A volta dos ursos ao espaço edênico das velhas montanhas de onde partiram, levando consigo o bem-amado rei, mais do que representar uma utopia regressiva, 
talvez seja uma constatação de que a vida nada mais é do que uma viagem rumo à morte, pois é esta que lhe dá sentido e permite ao homem reintegrar-se no cosmos: "Onde foi enterrado o Rei Leôncio? Em que bosque de abetos, em que pasto verde, no coração de qual rochedo? Ninguém nunca soube, é provável que não se saiba jamais" (BUZZATI, 2011, p. 128). Disso deriva a circularidade da fábula narrada, a qual, quando começa, já tem um fim traçado, e, quando termina, volta ao início, ao princípio de tudo. Essa reflexão sobre a inelutabilidade do destino do homem é serena, porque o escritor, além de não temer "a querida morte" ${ }^{17}$, se dirige aos mais jovens. Ela, porém, não deixa de ter algumas pinceladas de melancolia, como quando os ursinhos se despedem das crianças, único momento em que Buzzati põe em cena o público ao qual a obra se destina.

Quando A famosa invasão dos ursos na Sicília foi gerada, a literatura italiana trilhava outros caminhos, com a afirmação do neorrealismo e suas histórias da vida real, quase documentais. O escritor, no entanto, sempre foi um outsider, pois o fato de não pertencer a nenhuma corrente artística lhe deu uma margem de liberdade incomum. Se, na pintura, havia se voltado para a arte figurativa, que lhe permitia narrar uma história com tintas e pincéis, sem abdicar do fantástico, ao escrever preferiu afastar-se da representação da realidade. Isso, no entanto, não significou dar-Ihe as costas, pois é das dobras da realidade que Buzzati faz brotar, sem carregar nas tintas, aqueles elementos dissonantes que põem em xeque a racionalidade, que desencadeiam o insólito. Por isso o recurso constante à alegoria que lhe permite refletir sobre a sociedade e o presente, mesmo nas fábulas aparentemente mais inocentes. Dessa forma, a ficção é transformada em realidade outra, paralela à dos fatos concretos do dia a dia.

O que Buzzati propõe é cruzar a fronteira que separa o cotidiano do fantástico e cabe a nós, leitores - crianças ou adultos -, a decisão de embarcar nessa viagem rumo à magia da ficção.

\section{Referências bibliográficas}

ADAMOVIT, R. La foresta delle tele parlanti. 2013. Disponível em: <www. lindro.it/.../69473-la-foresta-delle-tele-parlanti...>

\footnotetext{
${ }^{17}$ La cara morte: é como deveria ter-se chamado o romance ilustrado Poema a fumetti (Poema em quadrinhos, 1969), em que a saga de Orfeu e Eurídice foi modernizada.
} 
Acesso em 18 dez. 2014

BUZZATI, D. A famosa invasão dos ursos na Sicília. Trad. Nilson Moulin. São Paulo: Berlendis \& Vertecchia Editores, 2001.

. La famosa invasione degli orsi in Sicilia. In: Opere scelte. Milano: Mondadori, 2002, p. 221-332. . I miracoli di Val Morel. Milano: Mondadori, 2012.

CARNAZZI, G. Cronologia. In: BUZZATI, D. Poema a fumetti. Milano: Mondadori, 2010, p. XXXV-L.

CARNAZZI, G. Introduzione. In: BUZZATI, D. Opere scelte. Milano: Mondadori, 2002, p. VII-L.

DORFLES, G. II fumetto tra disegno e racconto. In: GIANNETTO, N.; GALLINA, M. (Org.). "Poema a fumetti" di Dino Buzzati nella cultura degli anni '60 tra fumetto, fotografie e arti visive. Milano: Mondadori, 2005, p. 3-8.

LAZZARATO, F. Um livro para todos. In: BUZZATI, D. A famosa invasão dos ursos na Sicília. Trad. Nilson Moulin. São Paulo: Berlendis \& Vertecchia Editores, 2001, p. 133-153.

MARCHESE, M. Buzzati per ragazzi: la natura. 16 jan. 2016. Disponível em: <http://www.lacooltura.com/2016/01/buzzati-per-ragazzi>. Acesso em: 13 jul. 2016.

MARTINI, E. II contrappunto tra la vita e la morte: la ballata macabra nel mondo di Dino Buzzati. Disponível em: <http://www.academia.edu/9032686/ il_contrappunto_tra_la_vita_e_la_morte_la_ballata_macabra_... .

Acesso em 13 jul. $201 \overline{6}$.

S.A. Dino Buzzati. In: BUZZATI, D. Un amore. Milano: Mondadori, 1985, p. 5-16 [sem autoria].

S.A. Dino Buzzati. In: BUZZATI, D. La boutique del mistero. Milano: Mondadori, 2015, p. V-XIII.

TOSCANI, C. Introduzione. In: BUZZATI, D. II segreto del Bosco Vecchio. Milano: Mondadori, 2014, p. V-IX.

V.A. I fumetti e le immagini che cambiarono I'Italia. In: GIANNETTO, N.; GALLINA, M. (Org.). "Poema a fumetti" di Dino Buzzati nella cultura degli anni '60 tra fumetto, fotografie e arti visive. Milano: Mondadori, 2005, p. 9-36.

TRUGLIO, M. Dino Buzzati's La famosa invasione degli orsi in Sicilia and the possibilities of children's literature. California Italian Studies Journal, ano 2, n. 2, 2011. Disponível em: <http://escholarship.org/uc/item/1963d93x>. 
Acesso em 13 jul. 2016.

VIGANÒ, L. Introduzione-La discesa nell'Aldilà: I'ultimo viaggio di Dino Buzzati. In: BUZZATI, D. Poema a fumetti. Milano: Mondadori, 2010, p. V-XXXIV. 